\title{
Aplikasi Teknologi Watertreatment Dengan Menggunakan Metode Elektrokoagulasi Untuk Perbaikan Kualitas Air Limbah Tahu
}

\author{
(Application of Watertreatment Technology Using Electroagulation Method for improving \\ waste water quality)
}

\author{
Indah Nandayani ${ }^{1}$, Ratna $^{1}$, Darwin $^{1}{ }^{*}$ \\ ${ }^{1}$ Program Studi Teknik Pertanian, Fakultas Pertanian, Universitas Syiah Kuala \\ *Corresponding author: Darwin_ae@unsyiah.ac.id
}

\begin{abstract}
Abstrak. Limbah cair industri tahu umumnya memiliki kandungan COD,BOD,Electrical Conductivity, Alkalinity, VS dan TS yang melebihi baku mutu yang dipersyaratkan. Elektrokoagulasi merupakan salah satu alternatif pengolahan limbah yang memanfaatkan listrik dan plat logam sebagai anoda dan katoda. Tujuan penelitian ini adalah untuk mengetahui pengaruh waktu kontak terhadap parameter uji Penelitian dilakukan dengan skala laboratorium menggunakan reaktor Elektrokoagulasi dengan menggunakan bantuan Plat Aluminium sebagai penghantar listrik. Waktu kontak yang digunakan 120 menit. Hasil penelitian menunjukkan proses elektrokoagulasi terbaik dengan dengan waktu pengolahan 120 menit pada proses penelitian dengan sumber listrik konvensional (PLN). Proses elektrokoagulasi dengan biaya operasi terkecil adalah menggunakan sumber listrik dari power supplay adaptor,Penelitian ini dilakukan dengan dua kali percobaan dan sampel cairan limbah tahu digunakan sebanyak $3500 \mathrm{ml}$.
\end{abstract}

Kata Kunci: Limbah cair tahu, elektrokoagulasi, Supply Power Adaptor, elektrolit pendukung

\begin{abstract}
Abst2a44ract : Tofu industrial wastewater generally contains COD, BOD, Electrical Conductivity, Alkalinity, VS and TS which exceed the required quality standards. Electrocoagulation is an alternative waste treatment that utilizes electricity and metal plates as anode and cathode. The purpose of this study was to determine the effect of contact time on test parameters. The research was conducted on a laboratory scale using an electrocoagulation reactor using an aluminum plate as an electrical conductor. The contact time used is 120 minutes. The results showed the best electrocoagulation process with a processing time of 120 minutes in the research process with a conventional power source (PLN). The electrocoagulation process with the lowest operating cost is to use a power source from the power supply adapter. This research was carried out with two experiments and $3500 \mathrm{ml}$ of tofu waste liquid sample was used.
\end{abstract}

Keywords: Tofu liquid waste, electrocoagulation, Power Supply Adapter, supporting electrolytes

\section{PENDAHULUAN}

Limbah merupakan salah satu permasalahan lingkungan saat ini. Permasalahan terjadi karena banyaknya pembuangan limbah secara sembarangan tanpa memperdulikan dampak negatif dari limbah tersebut, seperti pencemaran terhadap sungai, tanah maupun kesehatan lingkungan. Salah satu penyebab terjadinya pencemaran adalah banyaknya air limbah yang dibuang tanpa melalui pengolahan lebih dahulu atau sudah diolah tetapi belum memenuhi persyaratan. Hal ini dimungkinkan karena adanya keengganan mengolah air limbah, disamping itu belum tersedianya sebuah teknologi pengolah air limbah yang mudah dan efisien sehingga dapat diterapkan di sebuah industri. Industri tahu merupakan salah satu industri yang berkembang pesat di Indonesia, khususnya di Banda Aceh.

Industri tahu dalam proses pengolahannya menghasilkan limbah padat maupun cair. limbah yang dihasilkan berasal dari proses pencucian, perebusan, pengepresan, dan pencetakan tahu (Rossiana, 2006). Karakteristik dari limbah tahu yaitu mengandung bahan organik yang tinggi dan memiliki $\mathrm{pH}$ rendah, yaitu 4-5. Berdasarkan kondisi tersebut, maka air limbah industri tahu merupakan salah satu sumber pencemaran yang potensial apabila air limbah yang dihasilkan langsung dibuang ke badan air (Herlambang, 2002). 
Untuk menyelesaikan masalah tersebut, air limbah perlu mengalami proses pengolahan terlebih dahulu menggunakan proses elektrokoagulasi dengan prinsip mengalirkan arus listrik dari anoda menuju katoda dimana kedua elektroda ini akan menarik materi pencemar menjadi flok yang dapat dengan mudah diendapkan dan dipisahkan sehingga air yang tercemar akan kembali menjadi bersih. Dalam proses elektrokoagulasi menggunakan elektroda plat aluminium agar mudah mengalami oksidasi ,Selain itu peralatan yang diperlukan sangat sederhana dan juga elektroda yang digunakan mudah dan terjangkau.Berdasarkan teori,polutan pada air limbah bisa dilakukan dengan usaha pengolahan dan pemisahan dengan proses yang sederhana dan hasil yang baik Teknologi yang bisa diterapkan adalah elektrokoagulasi yang dilanjutkan dengan flotasi. Gabungan (hybrid) teknologi ini cukup sederhana karena hanya memanfaatkan proses fisika saja. Luas lokasi yang dibutuhkan tidak terlalu besar sehingga teknologi ini cocok diterapkan pada industri kecil dan menengah..

\section{METODE PENELITIAN}

Alat yang digunakan pada penelitian ini adalah $\mathrm{pH}$ meter, kabel penghubung, aquarium kaca akrilik, timbangan analitik, kertas saring, gelas beker, gelas erlemenyer, biuret, Pipet Tetes, Botol winkler, Labu Ukur, Oven, Power supply Adaptor,sikat tabung, sarung tangan dan plat aluminium dengan panjang $25 \mathrm{~cm}$, lebar $15 \mathrm{~cm}$ dengan ketebalan 0,5 $\mathrm{mm}$. Bahan yang digunakan dalam penelitian ini adalah limbah cair tahu, aquades, $\mathrm{pH}$ buffer, larutan $\mathrm{CaCl}_{2}$, larutan MnSo4 10\%, kertas saring,dan larutan $\mathrm{H} 2 \mathrm{So} 4$.

\section{Prosedur Penelitian}

\section{Persiapan dan Karakteristik Cairan Limbah Tahu}

Limbah tahu yang berada dalam drum penampungan yang berasal dari pabrik Produksi Tahu Sumedang Timbul Jaya, Gampong Geuceu, Kayee Jathoe Banda Aceh. Pada percobaan cairan limbah tahu diambil sebanyak $3500 \mathrm{ml}$, kemudian dilakukan karakterisasi bahan, meliputi pH. Penelitian ini dilakukan selama 120 menit dan setiap per 10 menit di cek kadar pH sampai selesai percobaan.

\section{Rangkaian Alat Elektrokoagulasi}

Pada penelitian ini menggunakan adaptor, penjepit, elektroda yang telah dibersikan, Elektroda yang digunakan adalah plat Luminium dengan ukuran panjang $25 \mathrm{~cm}$, lebar $15 \mathrm{~cm}$ dengan ketebalan 0,5 mm. .dirangkai kawat AL dibuat melingkar sampai batas larutan pada wadah elektrolisis, dipasang elektroda AL tegak lurus pada tengah lingkaran kawat, kemudian sambungkan adaptor pada kabel penghubung (kabel buaya) pada kutub negatif dan kutub.

\section{Analisa Terhadap Waktu}

Seperangkat alat elektrokoagulasi, masukkan sebanyak $3500 \mathrm{~mL}$ sampel limbah cair tahu, kemudian disambungkan kabel penghubung kutub negatif dan kutub positif pada elektroda. Selanjutnya dilakukan elektrolisis dan diatur kuat tegangan adaptor pada tegangan 110Volt. Dinyalakan adaptor dengan waktu kontak selama 120 menit. Dipisahkan cuplikan hasil elektrolisis lalu dianalisa. Ditentukan waktu optimum dari parameter tersebut berdasarkan perubahan warna sampel menjadi bening.

\section{Analisis Hasil Elektrokoagulasi}

Pengujian parameter limbah cair tahu yang di hitung meliputi $\mathrm{pH}$. Pengujian nilai $\mathrm{pH}$ dilakukan di Labolatorium Pasca Panen, Program Studi Teknik Pertanian, Fakultas Pertanian Universitas Syiah Kuala, Banda Aceh menggunakan Alat benchtop meter. 


\section{Pengujian pH}

Pengujian $\mathrm{pH}$, dilakukan dengan menggunakan alat benchtop meter. Cara pengujian tergolong sederhana yaitu dengan mencelupkan sensor pada alat kedalam sampel limbah cair tahu, kemudian nilai dari $\mathrm{pH}$ akan ditampilkan pada layar benchtop meter.

\section{HASIL DAN PEMBAHASAN}

\section{Limbah Cair Tahu}

Limbah cair industri tahu mengandung bahan-bahan organik kompleks yang tinggi terutama protein dan asam-asam amino dalam bentuk padatan tersuspensi maupun terlarut. Adanya senyawa-senyawa organik tersebut menyebabkan limbah cair industri tahu mengandung BOD, COD dan TS yang tinggi. Limbah ini sering dibuang secara langsung tanpa pengolahan terlebih dahulu sehingga menghasilkan bau busuk dan mencemari lingkungan. Penelitian ini dilakukandengan menggunakan pasangan elektroda aluminium sebagai anoda dan katoda. Penelitian ini dimaksudkan untuk mengurangi kadar limbah cair tahu yang diolah berupa dan derajat keasaman $(\mathrm{pH})$.

\section{Derajat Keasaman}

Data Hasil Pengukuran pH selama proses watertreatment elektrokoagulasi dapat dilihat pada Gambar 1

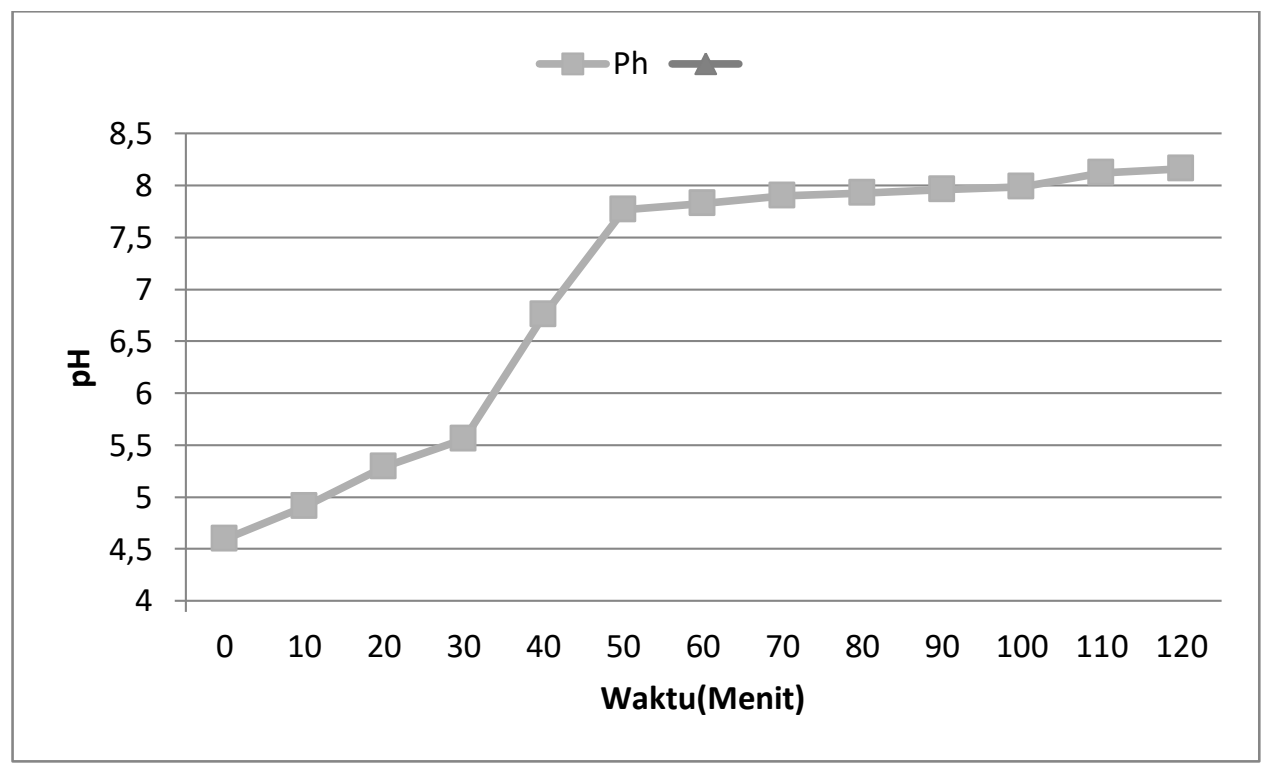

Gambar 1. Derajat Keasaman $(\mathrm{pH})$

Pada proses elektrokoagulasi elektroda yang digunakan (alumunium ) akan larut atau keropos karena arus listrik yang diberikan ke anoda akan melarutkan alumunium kedalam larutan yang kemudian bereaksi dengan ion hidroksi dari katoda membentuk alumunium hidroksi yang mengkoagulasi dan flokulasi atau pengendapan partikel tersuspensi. perubahan $\mathrm{pH}$ yang berarti dan ada kecenderungan stagnan pada penggunaan empat plat $\mathrm{Al}$, hal ini dimungkinkan karena ion $\mathrm{Al}+2$ dapat menimbulkan suasana basa dalam limbah. Sehingga Pada proses elektrokoagulasi $\mathrm{pH}$ akan meningkat karena ion hidroksi yang dihasilkan lebih banyak. (Holt P, dalam Prabowo Agung, 2012). 
Elektrokoagulasi seringkali dapat menetralisir muatan-muatan partikel dan ion, sehingga bisa mengendapkan kontaminan - kontaminan, menurunkan konsentrasi lebih rendah dari yang bisa dicapai dengan pengendapan kimiawi, dan dapat menggantikan dan/ atau mengurangi penggunaan bahan-bahan kimia yang mahal (garam logam, polimer). Sedangkan tingkat efektivitas tertinggi setelah proses elektrokoagulasi yaitu $\mathrm{pH}$ 8.Berdasarkan Gambar 1 terlihat bahwa nilai $\mathrm{pH}$ limbah cair tahu sebelum dan sesudah pengolahan pada percobaan mengalami peningkatan. Sebelum dilakukan pengolahan (influent), nilai $\mathrm{pH}$ limbah cair tahu adalah 4,6. Kemudian pada saat setelah dilakukan treatment selanjutnya nilai $\mathrm{pH}$ selalu berada di atas nilai influent tersebut. Nilai $\mathrm{pH}$ selama dilakukan watertreatment elektrokoagulasi mengalami kenaikan dalam posisi basa yakni dalam rentang $\mathrm{pH}$ 4,6-8,16 dengan nilai setelah pengolahan (effluent) adalah 7,15.

Derajat keasaman adalah ukuran untuk menentukan sifat asam dan basa. Perubahan $\mathrm{pH}$ di suatu air sangat berpengaruh terhadap proses fisika, kimia, maupun biologi dari organisme yang hidup di dalamnya Derajat keasaman diduga sangat berpengaruh terhadap daya racun bahan pencemaran dan kelarutan beberapa gas, serta menentukan bentuk zat di dalam air. Nilai $\mathrm{pH}$ air digunakan untuk mengekspresikan kondisi keasaman (konsentrasi ion hidrogen) air limbah. Skala pH berkisar antara 1-14. Kisaran nilai pH 1-7 termasuk kondisi asam, pH 7-14 termasuk kondisi basa, dan pH 7 adalah kondisi netral (Wardhana, 2004). Peningkatan $\mathrm{pH}$ disebabkan oleh aktivitas elektroda Elektrokoagulasi menetralisir muatanmuatan partikel dan ion, sehingga bisa mengendapkan kontaminan-kontaminan, menurunkan konsentrasi lebih rendah dari yang bisa dicapai dengan pengendapan kimiawi, dan dapat menggantikan dan/atau mengurangi penggunaan bahan-bahan kimia yang mahal (garam logam, polimer). Meskipun mekanisme elektrokoagulasi mirip dengan koagulasi kimiawi dalam hal spesies kation yang berperan dalam netralisasi muatan-muatan permukaan, tetapi karakteristik flok yang dihasilkan oleh elektrokoagulasi berbeda secara dramatis dengan flok yang dihasilkan oleh koagulasi kimiawi. (Woytowich, 1993).

Rendahnya nilai $\mathrm{pH}$ disebabkan oleh banyaknya padatan dalam air sehingga padatan dalam air yang terurai pada proses koagulasi ini menyebabkan nilai $\mathrm{pH}$ meningkat. Parameter $\mathrm{pH}$ merupakan faktor yang sangat penting yang harus diperhatikan selama proses watertreatment berlangsung. Nilai $\mathrm{pH}$ pada pengolahan menggunakan sistem elektrokoagulasi mengalami peningkatan dari 4,6 menjadi 8,16 yang juga disebabkan oleh kurangnya padatan yang terkandung dalam limbah cair tahu tersebut. Derajat keasaman $(\mathrm{pH})$ merupakan salah satu parameter yang menentukan kualitas limbah cair tahu, Karena pada proses elektrokoagulasi terjadi proses elektrolisis air yang mengahasilkan gas hidrogen dan ion hidroksida, maka dengan semakin lama waktu kontak yang digunakan, maka semakin cepat juga pembentukan gas hidrogen dan ion hidroksida, apabila ion hidroksida yang dihasilkan lebih banyak maka akan menaikkan $\mathrm{pH}$ dalam larutan. $\mathrm{pH}$ larutan juga mempengaruhi kondisi spesies pada larutan dan kelarutan dari produk yang dibentuk. $\mathrm{pH}$ larutan mempengaruhi keseluruhan efisiensi dan efektivitas dari proses elektrokoagulasi. 


\section{Kesimpulan}

\section{KESIMPULAN DAN SARAN}

1. Berdasarkan hasil penelitian dapat disimpulkan sebagai berikut : Derajat keasaman (pH) Limbah cair tahu berada pada posisi basa yakni berada pada rentang 4,6-8,16 yang artinya pada kondisi baik untuk proses perbaikan kualitas cairan limbah tahu dengan cara watertreatment elektrokoagulasi.

2. Hasil penelitian menunjukkan bahwa tegangan 110 Volt dan dengan waktu 120 menit pada proses elektrokoagulasi memberikan pengaruh terhadap penurunan kandungan bahan organik yang terdapat dalam limbah cair tahu.

3. Dari proses percobaan yang dilakukan membuktikan bahwa dengan menggunakan metode elektrokoagulasi mampu memperbaiki kualitas limbah cair tahu sehingga Saran cairan tahu aman jika di alirkan/dibuang sungai.

Sebaiknya dilakukan penelitian lanjutan dengan volume dan variasi tegangan lainnya lainnya dengan desain alat yang dapat memasukkan atau mengeluarkan bahan secara otomatis sehingga prosesnya lebih mudah.

\section{DAFTAR PUSTAKA}

Herlambang, A,. Dkk, 2002. Teknologi Pengolahan Limbah Cair Industri,Http://www.kelair .bppt.go.id/Publikasi/BakulimbahcairIndustri/Bukulimbahcairindustri.html.diakses 19 januari 2016.

Prabowo Agung, 2012. Pengolahan Limbah Cair yang Mengandung Minyak dengan Proses Elektrokoagulasi dengan Elektroda Besi.Jurnal Teknologi Kimia dan Industri, Vol.1, No.1.Tahun 2012. Halaman 352-355.

Rossiana, N .2006. Uji Toksitas Limbah Cair Tahu Sumedang Terhadap Repoduksi Daphnia Carinta KING. Hasil Penelitian Toksitologi Lingkungan. UNPAD.

Wardhana, W. A. 2004. Dampak Pecemaran Lingkungan. Yogyakarta . Andi Press.

Woytowich, 1993, Electrocoagulation (CURE) Treatment of ship Bilgewater for The U.S. Cost Guard in Alaska. Marine TechOogy Society Journal, Vol . 27. 1 p. 62, Spring 1993. 